\title{
COMBINING GIS, FUZZY LOGIC, AND AHP MODELS FOR SOLID WASTE DISPOSAL SITE SELECTION IN NASIRIYAH, IRAQ
}

\author{
AbDulhasan, M. J. ${ }^{1}$ - HANAFIAH, M. M. ${ }^{1 *}$ - SATChEt, M. S. ${ }^{2}-$ ABdUlaAli, H. S. ${ }^{3}-$ \\ TORIMAN, M. E. ${ }^{4}-$ AL-RAAD, A. A. ${ }^{1,5}$ \\ ${ }^{1}$ Center for Earth Sciences and Environment, Faculty of Science and Technology, Universiti \\ Kebangsaan Malaysia, 43600 Bangi, Selangor, Malaysia \\ ${ }^{2}$ Civil Engineering Department, University of Thi-Qar, Nasiriyah, Iraq \\ ${ }^{3}$ Department of Architecture, Faculty of Engineering and Built Environment, Universiti \\ Kebangsaan Malaysia, 43600 UKM Bangi, Selangor, Malaysia \\ ${ }^{4}$ School of Social, Development and Environmental Studies, Faculty of Social Sciences and \\ Humanities, Universiti Kebangsaan Malaysia, 43600 Bangi Selangor, Malaysia \\ ${ }^{5}$ Department of Biology, College of Science, Al-Muthanna University, Al-Muthanna \\ Governorate, Iraq \\ *Corresponding author \\ e-mail:mhmarlia@ukm.edu.my; phone:+60-3-8921-5865;fax:+60-3-8925-3357 \\ (Received $3^{\text {rd }}$ Feb 2019; accepted $8^{\text {th }}$ Apr 2019)
}

\begin{abstract}
Finding locations suitable for disposal of solid waste is one of the fundamental challenges facing municipal cities and environmental stability. The present study aims to identify the most suitable solid waste disposal site using Geographic Information System (GIS), remote sensing, and the multi criteria decision-making (MCDM) technique. In addition, the study compares the proposed method for suitability with the traditional analytic hierarchy process (AHP) approach. A new validation approach was applied to evaluate the accuracy of the AHP and Fuzzy logic methods based on the selected solid waste locations. Remote sensing data (ASTER GDEM) and field/reference maps were used to derive 12 conditioning factors required to produce a suitable location for solid waste disposal. The result shows that the accuracy of AHP, based on the consistency index (CI), is acceptable (greater than 0.1). However, Fuzzy logic was shown to be more accurate than AHP. The total surface areas of suitable locations based on AHP and Fuzzy models are $4.4 \mathrm{~km}^{2}$ and $13.35 \mathrm{~km}^{2}$, respectively. This study showed that AHP, Fuzzy logic and GIS can be integrated for waste management decision issues related to site selection to reduce negative effects on the environment and inhabitants.
\end{abstract}

Keywords: waste management, landfill site selection, remote sensing, multi-criteria decision analysis

\section{Introduction}

Selection of landfill locations for solid waste (SW) is determined by waste management operations based on multiple factors, including the geographic formation of a region. The decision for this selection is vested in governmental authorities (Hanine et al., 2016). Location selection for solid waste landfills is crucial for every region due to the cost implications, difficulty of reversal, and long-term commitment required (Gorsevski et al., 2012; Liu et al., 2014). Finding suitable location for landfills is also very challenging due to various factors, such as increasing waste quantities, population growth, environmental and public health risk factors, and decreasing land availability for waste disposal (Srivastava and Nema, 2012). Therefore, geographic information should not be the only criteria for site selection, however, flexibility to accommodate future changes should also be considered in regional policies. In determining solid waste disposal landfill sites, environmentally friendly and financially sound 
selection is a challenge. Selecting a suitable landfill location involves a considerable array of points, criteria, and verification of a given set of limitations to ultimately provide an optimal solution.

The analytic hierarchy process (AHP) method is one of the most commonly used methods for multi-criteria decision-making (MCDM) (Beskese et al., 2015; Moeinaddini et al., 2010). It is capable of solving complex decision-making problems across various fields (Saaty et al., 2000; Uyan, 2013; Tavares et al., 2011). It is also used to determine the consistency of weightings for criteria by constructing a matrix for pairwise comparisons. This combination provides an appropriate language to manage imprecision criteria and integrate qualitative analysis with quantitative factors.

Even though many researches have proposed the use of Fuzzy multi-criteria decisionmaking methods, very few have applied the combined use of these methods for the selection of suitable landfill location. Torabi-Kaveh et al. (2016) proposed a combination of Geographic Information System (GIS) with a Fuzzy analytical hierarchy process (FAHP) to determine suitable locations for landfill site in Iranshahr, Iran. Chabuk et al. (2017) combined GIS analysis and MCDM for selecting landfill locations in Al-Hashimiyah Qadhaa, Babylon, Iraq. Foroughian and Eslami (2015) presented a study using GIS and AHP indicators for identification of solid waste disposal landfill sites in the city of Susa. Various techniques have been utilized for selecting landfill locations (Gbanie et al., 2013; Khorram et al., 2015; El Baba et al., 2015; Rathore et al., 2016). These authors determined that a combined evaluation using MCDM methods in landfill location selection is imperative. This is due to the fact that relative advantages of several methods depend on the characteristics of the problem domain.

The present study aims to determine a suitable disposal site using Fuzzy logic approach and justify the approach by comparing with traditional AHP approach, which is used for determination of suitable waste disposal sites in Nasiriyah, Iraq. Currently, there is only one available landfill site in Nasiriyah and it does not meet the relevant scientific and environmental standards. The main objective of this paper is to propose the best method for identification of solid waste disposal sites that is suitable for Nasiriyah, Iraq, and fulfills environmental and scientific criteria.

\section{Materials and methods}

The map layers were prepared using GIS and cover the most important 12 criteria in the study area. The landfill site selection model is illustrated in Figure 1. The raster maps of selected criteria were prepared and the final map of landfill siting was produced in the GIS software. Each raster map for the selected criteria was divided into categories, with each category is given appropriate weight. The final map of landfill siting was determined using GIS single output map algebra. The methodology and framework adopted in this study is presented in Figure 1.

\section{Study area}

This research was conducted in Nasiriyah, Iraq. The Governorate of Thiqar is located to the south of Iraq at the intersection of longitude $31^{\circ} 01^{\prime} \mathrm{E}$ to $31^{\circ} 08^{\prime} \mathrm{E}$ and latitude $46^{\circ} 08^{\prime} \mathrm{N}$ to $46^{\circ} 18^{\prime} \mathrm{N}$. The city of Nasiriyah is the administrative center of the governorate and is 380 $\mathrm{km}$ to the south of Baghdad and $214 \mathrm{~km}$ to the north of Basra City. The total area is 12,900 $\mathrm{km}^{2}$, equivalent to $5,160,000$ acres. The desert land area covers $6.7 \%$ of the governorate and has a population of about 1.99 million. This population is expected to grow significantly over the next decade as a result of significant economic and security improvements. It is also home 
to the largest marshlands of Iraq, with an area of 1,048,600 acres, which is $3.1 \%$ of the total area of Iraq. Figure 2 shows the map of the area.

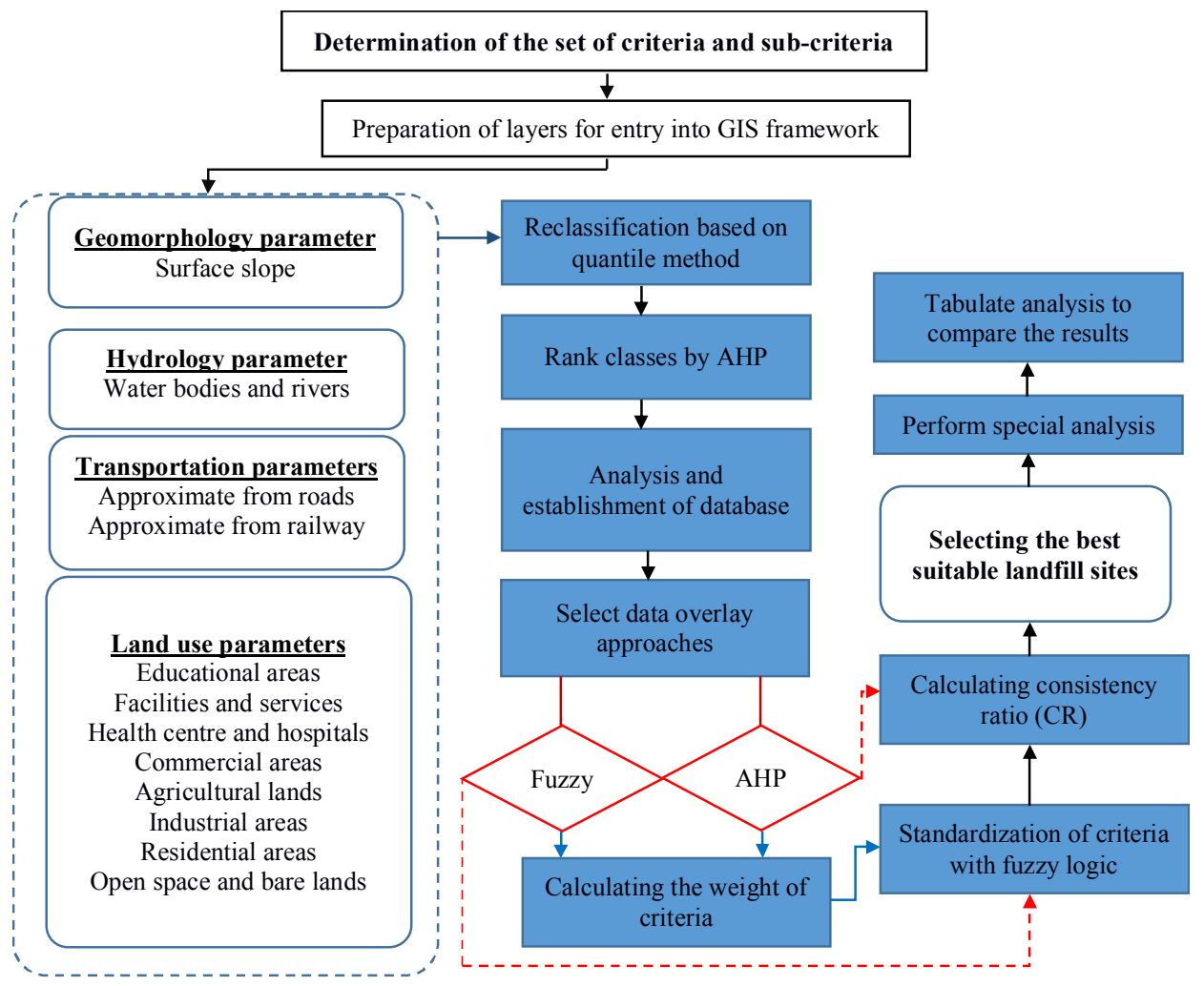

Figure 1. Conceptual framework of the present study

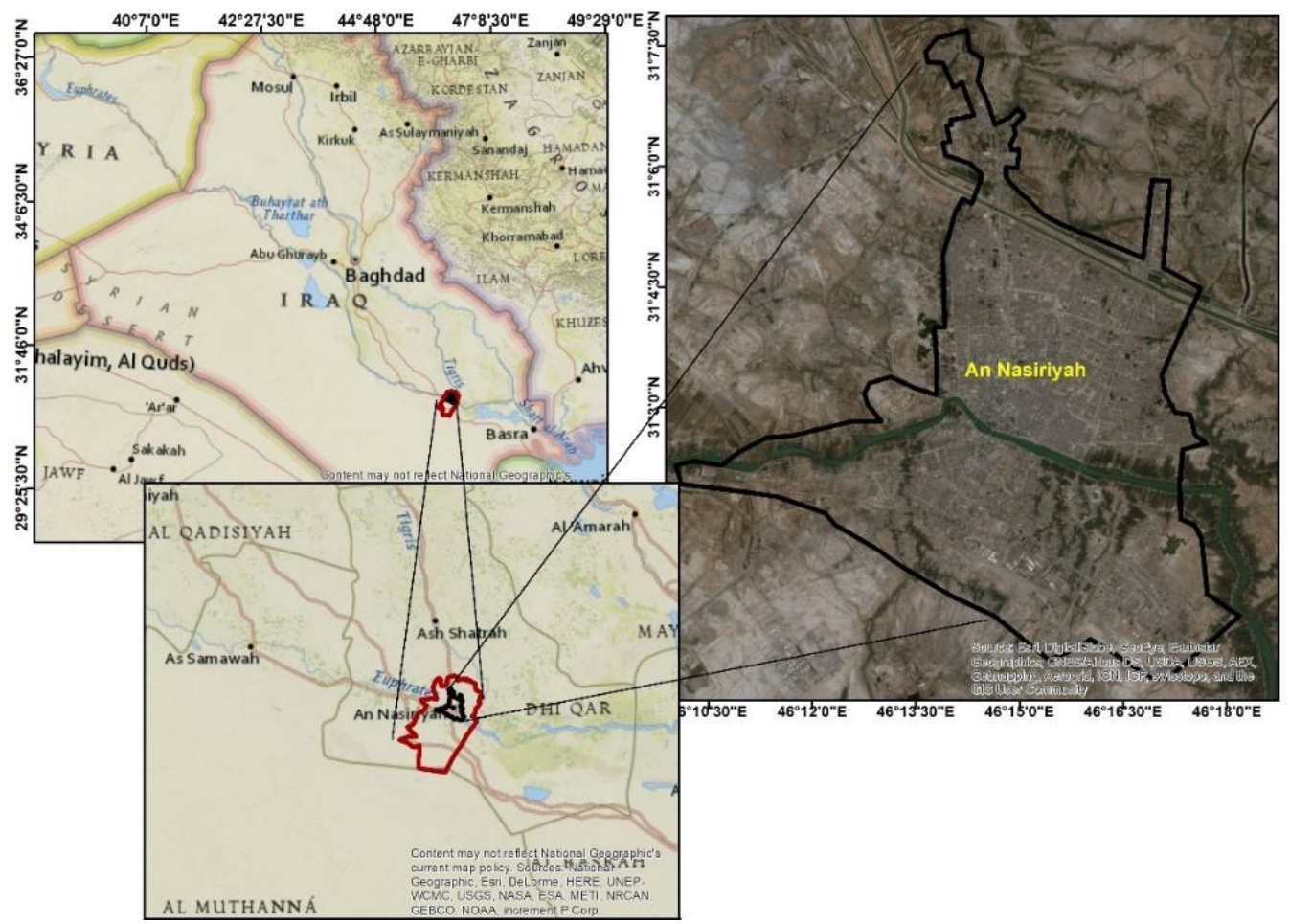

Figure 2. Map of the study area 


\section{Suitability criteria}

In this study, 12 criteria were derived from 4 main criteria to determine suitable areas for solid waste disposal sites; these criteria were slope, distance from bodies of water, distance from roads, distance from railways, distance from open space, distance from agricultural lands, distance from health centers and hospitals, distance from residential areas, distance from commercial areas, distance from industrial areas, distance from facilities, and distance from educational areas, as shown in Table Al in the Appendix and Figure 3.

\section{Analytic hierarchy process}

Due to its simplicity and robustness in finding weights and combining heterogeneous data, AHP has been applied for MCDM, conflict management, total quality management, suitability analysis, resource allocation, design, and engineering (Jiang and Eastman, 2000; Vaidya and Kumar, 2006; Gorsevski et al., 2006; Şener et al., 2010; Vasiljević et al., 2012). In addition, it has been applied in many practical applications across fields, including site selection (Abdullahi et al., 2014). The various factors considered are not of equal importance in the determination of a potential solid waste site, therefore, the importance of each parameter was identified. In terms of the suitability of a solid waste site, hydrological formation has more importance in weight than distance from railways. Therefore, a weighted linear combination (WLC) was used in this study, in line with Drobne and Lisec (2009) and Kritikos and Davies (2011). It can be considered a hybrid of qualitative and quantitative techniques (Ayalew et al., 2004).

\section{Determination of weights}

The MCDM module was used for the weight-selecting criteria (Drobne and Lisec, 2009). A pairwise comparison referred to as the analytic hierarchy process developed by Saaty (1980) was used in this study. This method includes the comparison of each factor against every other factor in pairs (Chang et al., 1996). The weights of criteria in Saaty's technique were computed by applying the main eigenvector of the square reciprocal matrix of the pairwise comparisons between the two factors (Drobne and Lisec, 2009). The pairwise comparison evaluates the two criteria against each other to determine the most important criteria for a given objective.

\section{Estimating consistency of pairwise comparisons}

The accuracy of pairwise comparisons was evaluated by calculating the consistency ratio $(\mathrm{CR})$, which is the ratio of the consistency index $(\mathrm{CI})$ and the randomness index (RI). CR was used to estimate the relative weightings of all criteria on a consistency ratio in which values under $10 \%$ are considered acceptable. Otherwise, the consistency ratio allows for reevaluation of comparisons. Table A2 shows the RI developed by Saaty et al. (1977), based on the order of the matrix according to the number of criteria. Equations 1 and 2 show the consistency ratio and consistency index, respectively.

$$
\mathrm{CR}=\frac{\mathrm{CI}}{\mathrm{RI}}
$$


CI is calculated using Equation 2:

$$
\mathrm{CI}=\frac{\lambda \max -\mathrm{n}}{\mathrm{n}-1}
$$

where: $\lambda \max =($ Weight $1 * \mathrm{~S} 1+$ Weight $2 * \mathrm{~S} 2+$ Weight $3 * \mathrm{~S} 3+$ ) and $n=$ number of criteria.
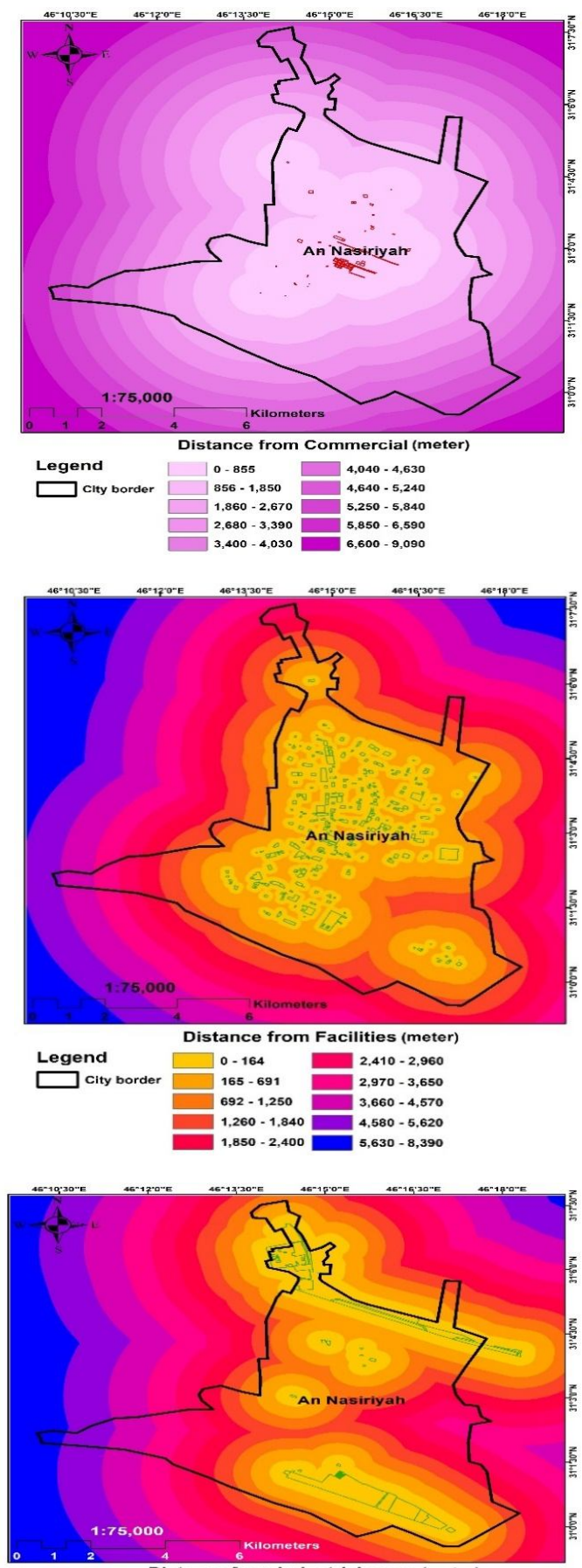

Legend

Distance from Industrial areas (meter) $0-403 \quad 2,460-3,090$

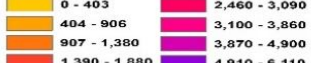
$1,390-1,880-1,910-6,110$
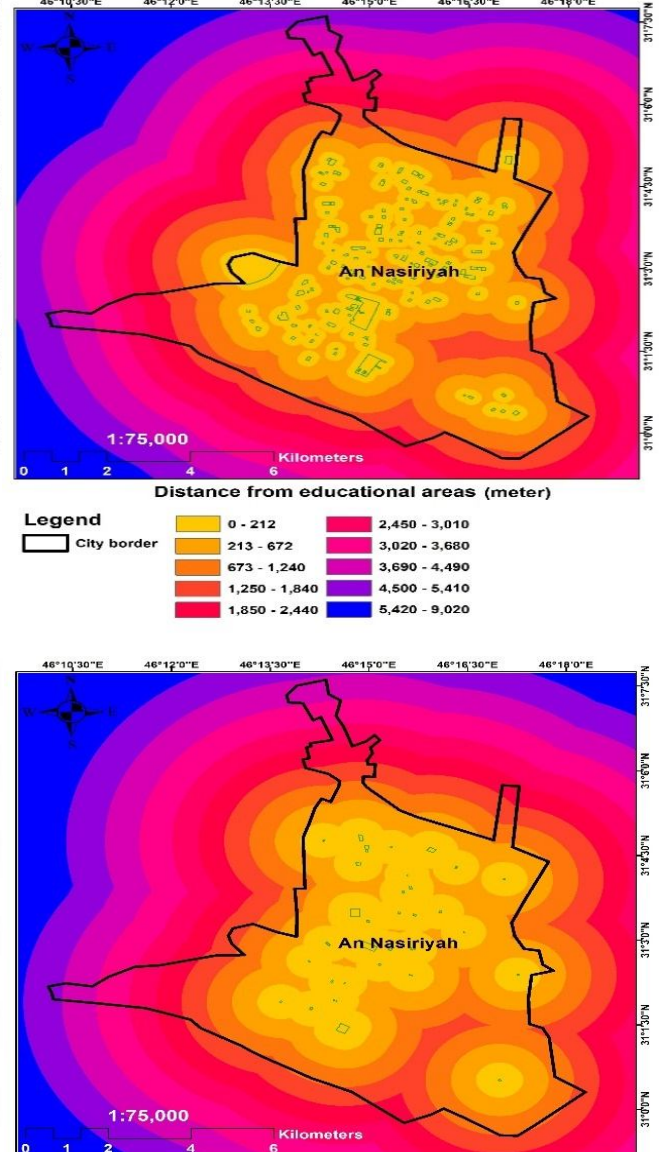

Distance from health centers and hospitals (meter) Legend

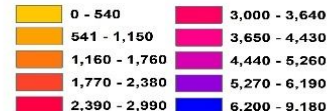

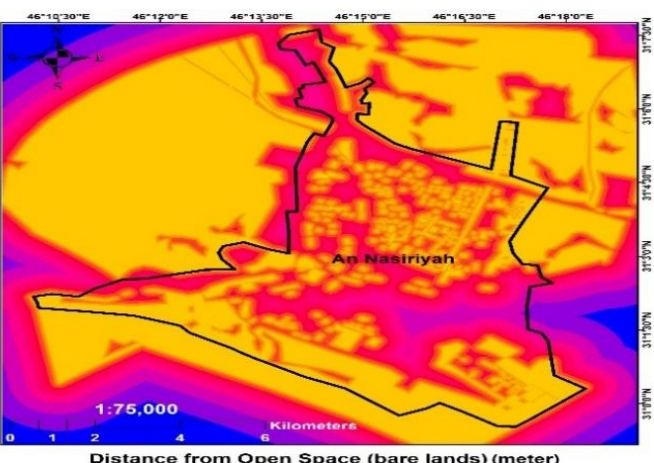

Distance from Open Space (bare lands) (meter) Legend

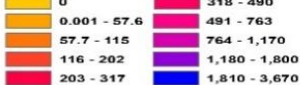



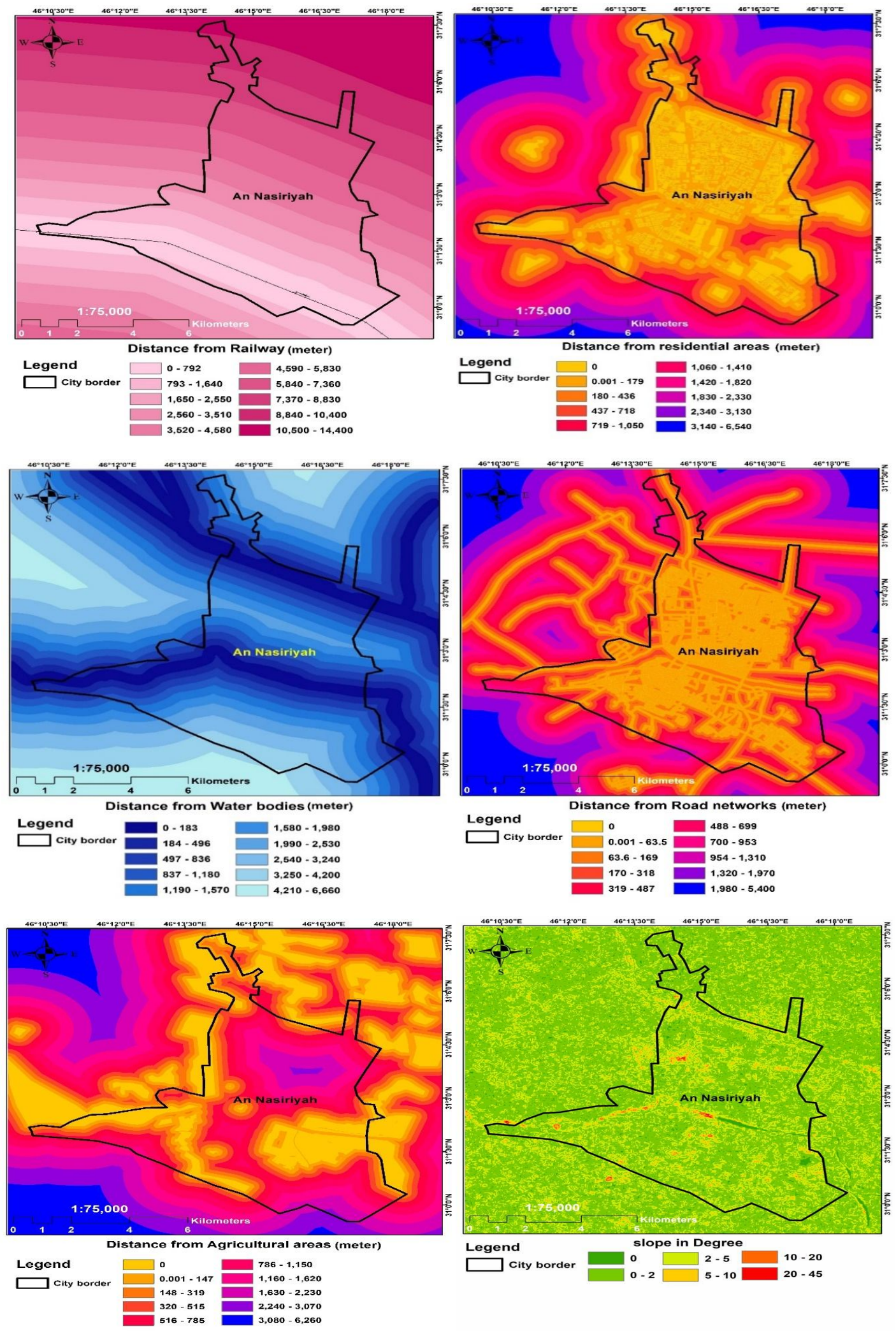

Figure 3. Suitability indexes in the current study; slope, distance from water bodies, distance from roads, distance from railways, distance from open space, distance from health centres and hospitals, distance from commercial areas, distance from agricultural lands and distance from industrial areas 


\section{Application of the fuzzy logic model}

In a Fuzzy approach, suitability of land is mapped by pixels of causal factor layers. Pixel values are numeric and range from 0 to 1 , from not suitable to very suitable. Pixel values must be within the range of 0 to 1 , although there is no practical constraint on the choice of the values. Values can be chosen to reflect the degree of membership of a set based on subjective judgment (Amato et al., 2018) or can be derived by various functions representing reality (Eastman et al., 2003). In this study, linear functions were used to represent the reality function. Fuzzy logic is preferred for land suitability evaluation due to its ability to estimate land use suitability on a continuous scale, which helps to cope with vagueness and uncertainty (Elaalem et al., 2012). Site suitability application using Fuzzy logic comprises three steps, as shown below:

\section{Step 1: Normalization or standardization of land characteristics using fuzzy set models}

Fuzzy logic helps the user to determine the likelihood that a site is suitable or unsuitable. This step assigns values from 0 to 1 , with 0 being not likely or unsuitable and 1 being most likely or suitable (Elaalem et al., 2012). Thus, the higher Fuzzy value implies the ideal of the site. When assigning Fuzzy values, four types of membership need to be understood to choose the best fits of the analysis criteria. There are four types of membership function in Fuzzy systems: linear, small, large and Gaussian. In this study, the linear membership function was used to normalize the parameters, due to its dependence on input parameters. If the input parameters seem chaotic, similar to a time series, the Gaussian type of membership function would be suggested, otherwise, the linear type is recommended (Qiu et al., 2014). High Fuzzy membership is assigned to large or small values, and Fuzzy membership decreases at a constant rate. A triangular membership function is specified by three parameters $\{\mathrm{a}, \mathrm{b}, \mathrm{c}\}$ as shown in Equation 3 (Önüt and Soner, 2008):

$$
\text { Triangulation }(x ; a, b, c)=\left\{\begin{array}{cl}
0, & x \leq a \\
\frac{(x-a)}{(b-a)}, & a \leq x \leq b \\
\frac{(c-x)}{(c-b)}, & b \leq x \leq c \\
0, & c \leq x
\end{array}\right.
$$

\section{Step 2: Generation of the criteria map layers}

Fuzzy logic offers an alternative scaling approach, using linguistic variables to represent quantitative and qualitative criteria (Sreedevi et al., 2016). For quantitative criteria, such as return on resources, representation by a linguistic variable requires the definition of term sets, such as "very low," "low," "medium," "high," and "very high". In this study, linear membership function was used to normalize the parameters because it depends on input parameters. The linear membership function is suggested if the input parameter is not chaotic (Elaalem et al., 2012). This step assigns values from 0 to 1 , with 0 being not likely or unsuitable and 1 being most likely or suitable. The range between 0 and 1 for membership function corresponds to the intensity of importance of each criterion, which is obtained from the literature and experts' opinions. 


\section{Step 3: Generation of the overall land suitability map layers}

Once the appropriate Fuzzy membership value for data criteria is assigned, several reclassified surfaces showing values from 0 to 1 are generated (Klir and Yuan, 1995), and subsequently, the Fuzzy logic model is applied. This step is similar to weighted site selection, which is a site selection method that allows users to rank raster cells and assign a relative importance value to each layer so that different reclassified surfaces can be compared to each other. In order to complete this step, one of several Fuzzy overlay types must be chosen. In this study, the "AND" Fuzzy overlay type was used due to its ability to determine the best values in finding locations that meet all criteria (Qiu et al., 2014).

\section{Results and discussion}

\section{Classification of criteria}

Each criterion was classified into 10 classes based on the quantile model, except for slope, which was classified into six classes using GIS software. The results showed that variation in each class affects the rank of the class. In some criteria, values were close to the target and thus achieved a higher rank. For some other criteria, values far from the target were considered an advantage and given high weight. For instance, low-distance classes of the open space criteria are more suitable for waste landfill, while far-distance classes in education are more suitable for solid waste landfill allocation. Some criteria prioritize the middle classes; for example, landfill sites should be located neither too close nor too far from residential areas.

Figure 4 illustrates the weight variation in slope, distance from bodies of water, distance from roads, distance from railways, distance from open space, distance from agricultural lands, distance from health centers and hospitals, distance from residential areas, distance from commercial areas, distance from industrial areas, distance from facilities, and distance from educational areas. An indirect linear relationship between the average of each class and its ranking was found for slope indicates that flat areas are weighted higher than steep fields for landfill site selection.

A direct linear relationship was obtained for other criteria. The farther the distance from rivers, the higher the rank for landfill suitability, as shown in Figure 4. Greater distance from hospitals or health centers, roads, railways, agricultural lands, public facilities, educational areas, and commercial centers equates to a higher rank and suitability for landfill. For residential areas, the logarithmic relationship shows that distances too close or too far (greater than $3 \mathrm{~km}$ ) from residential areas receive a lower rank and are thus unsuitable for solid waste disposal. This is because if the distance is too close, the landfill can infect the inhabitants with diseases or odors, while placing dump sites too far away from the source of the waste is uneconomical and timeconsuming. Figure 4 also shows that the class too close or far from industrial areas, mostly out of the city, showed a lower rank for solid waste landfill.

Table A3 shows the classification and rank for 12 criteria based on the quantile method using GIS software. Six classes of slope show that a 0 degree angle of steepness achieved the highest rank using the AHP model, implying that these are the most suitable classes for landfill use. Inversely, the lowest classes are those with a 45 degree angle of steepness; these are ranked as 1 . Ten classes of distance from the river indicated that the class at an average of 91 meters away from the river had the lowest 
rank using the AHP model, thus is least suitable for landfill. Inversely, the most suitable class is ranked with 9, which is 3,721 m away from water bodies.

Table A3 also shows that the class at an average of $593 \mathrm{~m}$ away from roads achieved the highest rank of suitability for landfills, using the AHP model, while the lowest suitable classes, ranked number 1 , recorded the closest and farthest distance classes from the road ( 0 and 3,684 m). The highest suitable class that attained rank number 10 indicating the greatest distance from the railways $(12,393 \mathrm{~m})$ and from railway. For agricultural, commercial and residential areas, the highest suitable class gained ranking number 10 at distance of $7,688 \mathrm{~m}$ away from health centers, $2,730 \mathrm{~m}$ away from residential areas and 7,839 $\mathrm{m}$ away from commercial areas, respectively.

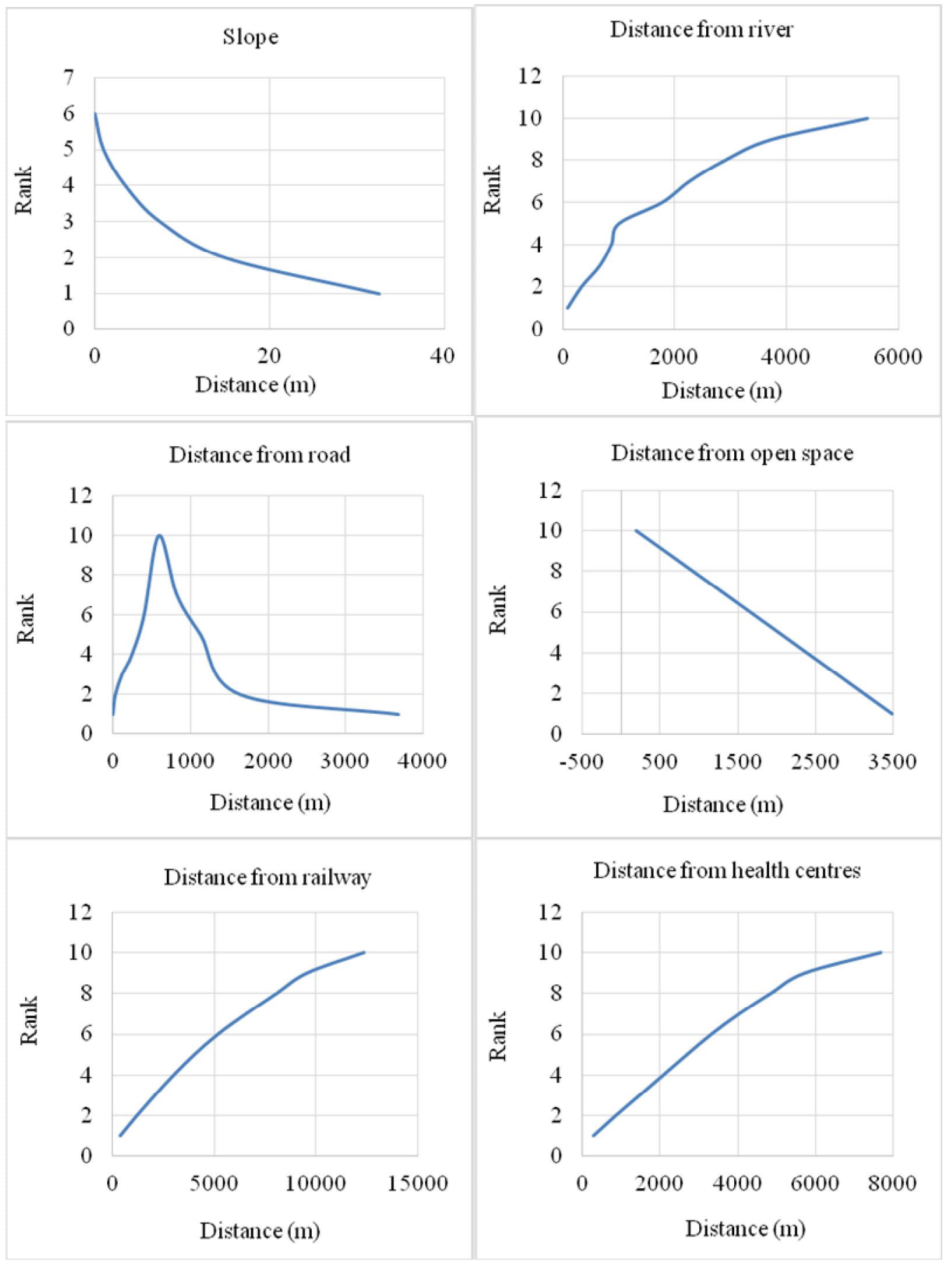






Figure 4. Weight variation in: slope, distance from river, distance from roads, distance from railways, distance from open space, distance from agricultural lands, distance from health centres and hospitals, distance from residential areas, distance from commercial areas, distance from industrial areas, distance from facilities areas and distance from education areas

Table A3 also shows that the highest suitable class for industrial areas and facilities ranked number 10 , representing an average distance from industrial areas of 2,770 m and from the facilities of 7,007 $\mathrm{m}$, respectively. The highest suitable class for education areas obtained ranking number 10 , which is the farthest distance from educational 
facilities $(7,216 \mathrm{~m})$. The soil stratification is not significantly contributed to the site selection as the study area has mostly covered by one soil type. In addition, due to the impervious surface of the study area, pollution might not be possible to deeply penetrate through the soil surface to groundwater. In contrary, there is a high chance to affect the surface water bodies.

\section{Selection of suitable sites for solid waste using the AHP model}

Questionnaires were prepared based on expert's response regarding to the most significant factors in the selection of suitable sites for a solid waste landfill in the study area. After the preparation of the conditioning factors using GIS, the weights of each factor were calculated using the geometric mean method to determine the final weight of each factor. Then, the factors were reclassified based on their weights and prepared using a raster calculator to generate a suitability map, which describes the suitable locations for solid waste landfill. The result of the pairwise comparison matrix obtained from questionnaires for the 12 criteria is shown in Table 1.

Table 1. Pairwise comparison matrix extracted from questionnaires for 12 criteria

\begin{tabular}{|c|c|c|c|c|c|c|c|c|c|c|c|c|}
\hline \multirow{2}{*}{$\begin{array}{c}\text { Pairwise } \\
\text { comparison } \\
\text { matrix }\end{array}$} & \multicolumn{12}{|c|}{ Solid waste landfill selection } \\
\hline & Res & Open & Road & Ind & Agri & Edu & Health & Faci & Com & Slope & Rail & WB \\
\hline Residential & 1 & 2 & 4 & 3 & 5 & 8 & 7 & 7 & 9 & 9 & 8 & 6 \\
\hline Open space & $1 / 2$ & 1 & 3 & 3 & 4 & 6 & 6 & 5 & 8 & 8 & 8 & 4 \\
\hline Road & $1 / 4$ & $1 / 3$ & 1 & $1 / 2$ & 2 & 5 & 4 & 3 & 6 & 7 & 6 & 2 \\
\hline Industrial & $1 / 3$ & $1 / 3$ & 2 & 1 & 1 & 4 & 3 & 3 & 5 & 5 & 6 & 2 \\
\hline Agricultural & $1 / 5$ & $1 / 4$ & $1 / 2$ & 1 & 1 & 3 & 2 & 2 & 5 & 5 & 5 & 1 \\
\hline Educational & $1 / 8$ & $1 / 6$ & $1 / 5$ & $1 / 4$ & $1 / 3$ & 1 & $1 / 3$ & $1 / 3$ & 2 & 3 & 4 & $1 / 4$ \\
\hline Health & $1 / 7$ & $1 / 6$ & $1 / 4$ & $1 / 3$ & $1 / 2$ & 3 & 1 & 1 & 4 & 6 & 5 & 1 \\
\hline Facilities & $1 / 7$ & $1 / 5$ & $1 / 3$ & $1 / 3$ & $1 / 2$ & 3 & 1 & 1 & 3 & 5 & 4 & $1 / 5$ \\
\hline Commercial & $1 / 9$ & $1 / 8$ & $1 / 6$ & $1 / 5$ & $1 / 5$ & $1 / 2$ & $1 / 4$ & $1 / 3$ & 1 & 2 & 2 & $1 / 6$ \\
\hline Slope & $1 / 9$ & $1 / 8$ & $1 / 7$ & $1 / 5$ & $1 / 5$ & $1 / 3$ & $1 / 6$ & $1 / 5$ & $1 / 2$ & 1 & $1 / 2$ & $1 / 7$ \\
\hline Railway & $1 / 8$ & $1 / 8$ & $1 / 6$ & $1 / 6$ & $1 / 5$ & $1 / 4$ & $1 / 5$ & $1 / 4$ & $1 / 2$ & 2 & 1 & $1 / 9$ \\
\hline River & $1 / 6$ & $1 / 4$ & $1 / 2$ & $1 / 2$ & 1 & 4 & 1 & 5 & 6 & 7 & 9 & 1 \\
\hline
\end{tabular}

$*$ Res $=$ Residential, Open = Open Space, Ind = Industrial, Agri = Agricultural, Edu = Educational, Faci

$=$ Facilities, $\mathrm{Com}=$ Commercial, Rail $=$ Railway, $\mathrm{WB}=$ Water Bodies

The pairwise comparison matrix shown in Table 1 was assembled from the input of 13 different experts in the field of environmental and waste management. The results were summarized based on the average of the distributed questionnaires. Table 2 shows the weight of each criteria in percentage and their ranks from the most to the least important criteria. It was deduced that proximity to residential areas was the most important criteria in solid waste selection. The second most important parameter was observed to be proximity to open space followed by distance from roads and industrial facilities. Inversely, the slope and distance from railways were determined to be the least important criteria in terms of landfill selection. 
Table 2. Weightage for criteria in percentage

\begin{tabular}{c|c}
\hline Criteria & AHP-Weightage (\%) \\
\hline Residential & 26.36 \\
Open Space & 19.63 \\
Road & 10.35 \\
Industrial & 10.13 \\
Agricultural & 7.19 \\
Educational & 2.97 \\
Health & 5.29 \\
Facilities & 4.58 \\
commercial & 1.97 \\
Slope & 1.40 \\
Railway & 1.63 \\
River & 8.50 \\
\hline
\end{tabular}

The accuracy of AHP is within acceptable limits, as the CI $(0.128)$ is greater than 0.1 . In addition, Lambda value of 13.41 and the Randomness Index (RI) with 1.54 were observed to show high accuracy based on the CI. The CI/RI ratio is 0.083 implying that the experts assigned the weight of each criterion logically, and the prioritization of the criteria was consistent. Figure 5 is a suitability map produced using the AHP model that shows the suitable areas in green and non-suitable areas in gray. It was observed that suitable areas were almost distributed across the entire study area. However, most suitable areas were found outside the city, mostly toward to the west and south of the study area. The overall area of very highly suitable lands for solid waste was found to be about $1.66 \mathrm{~km}^{2}$. Therefore, field visits are required to identify the final location of the solid waste landfill. The suitability map produced in GIS using AHP model shows that suitable sites are not clustered in one single area, but distributed over different locations within the study area. This indicates that some of the conditioning factors have a huge influence on the selection process for suitable sites and were distributed across the study area.

Suitable areas were determined using the AHP model and were mostly found far from urban areas, and no suitable area was observed around the city borders. These sites require further investigation to determine the possibility of constructing a solid waste disposal field.

\section{Selection of suitable sites for solid waste using the fuzzy model}

The suitability map produced using the Fuzzy model is presented in Figure 5. The map shows suitable and unsuitable locations in the study area, identified based on 12 factors for solid waste disposal. The map shows that most suitable areas are located in the middle and in the north part of the study area. On the other hand, the southern part of the study area was observed to have no identified suitable site for solid waste, thus, should be ignored in the field visit. The overall surface area of suitable land is estimated to be $13.35 \mathrm{~km}^{2}$. The suitability map produced using the Fuzzy model shows the spatial distribution of the suitable areas and their patterns in the study area. It can be observed that most of the suitable areas are clustered into groups and are not randomly scattered in different directions. This indicates that the suitable areas identified are homogenous 
and share similar characteristics with each other. This is very important for decision makers, as it makes final selection easier and more accurate. Decision makers can use this method to easily identify suitable areas for constructing solid waste landfill sites in a particular area.

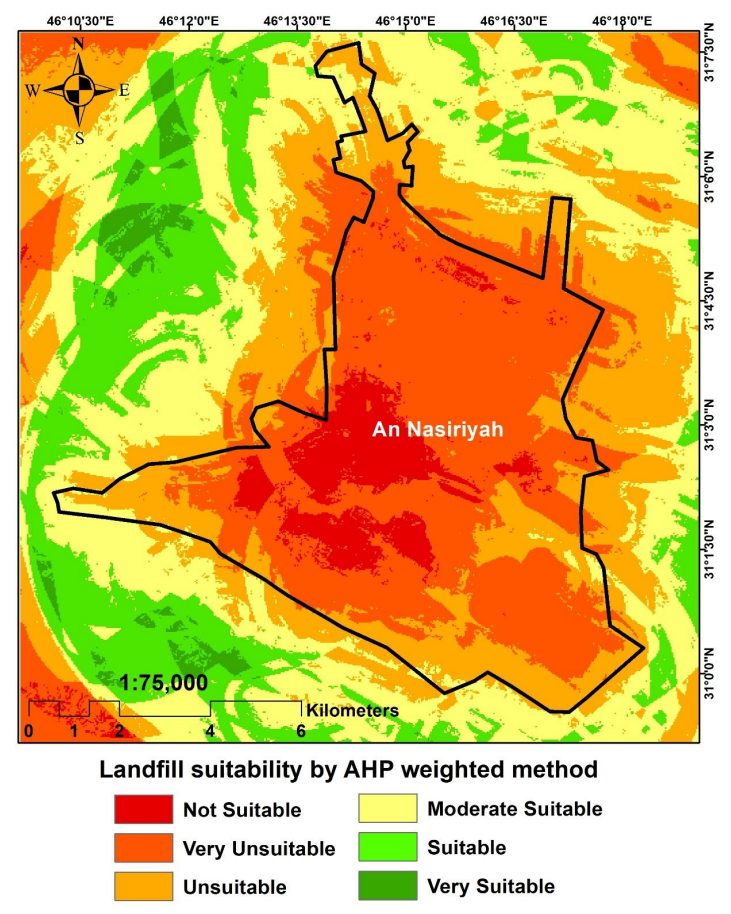

$\mathrm{a}$

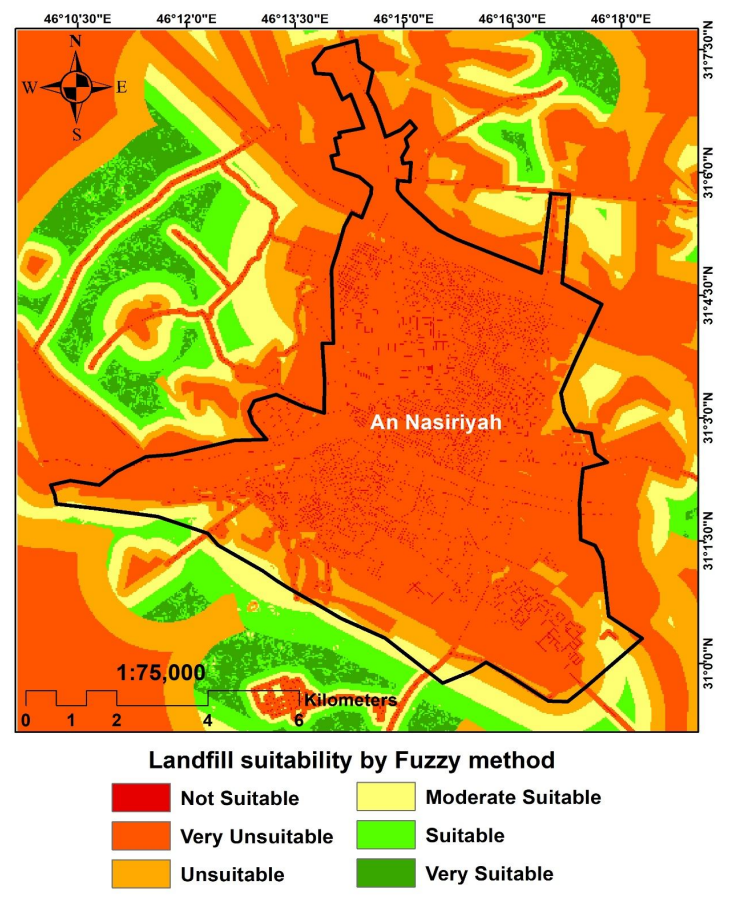

$\mathrm{b}$

Figure 5. Map produced using a) AHP model and b) fuzzy model

It is imperative to compare the results of the AHP and Fuzzy models to identify their similarities and possible differences. The comparison between the maps produced by these models showed that the AHP maps identified the suitable areas as scattered regions, while the Fuzzy model generated a map with clustered suitable areas. It was observed that the AHP map located suitable areas in almost all parts of the study area, while the Fuzzy map identified suitable areas at the middle and northern parts of the study area. In terms of the surface area of suitable lands identified, the AHP model indicated $4.14 \mathrm{~km}^{2}$ area as highly suitable, while the Fuzzy model identified $13.35 \mathrm{~km}^{2}$ as highly suitable for solid waste landfill. Figure 6 illustrates the percentage of landfill suitability based on the AHP and Fuzzy Models with 2\% and 5\% for very suitable areas.

Table 3 shows the results of the AHP model in terms of very suitable landfill areas, $4.14 \mathrm{~km}^{2}$, and very unsuitable areas, $60.6 \mathrm{~km}^{2}$. The Fuzzy model obtained $13.35 \mathrm{~km}^{2}$ for very suitable areas and $131.56 \mathrm{~km}^{2}$ for very unsuitable areas (Table 3). In addition, the Fuzzy model showed more areas considered very suitable compared to the AHP model, which could be due to the mathematical nature of the Fuzzy algorithm. The common areas identified by both methods showed the most suitable lands for waste disposal landfills, far away from residential areas and close to bare lands. Traditional AHP approach is more simplistic and robust while Fuzzy logic approach help in coping with vagueness and uncertainty of determining site suitability. The results further display that 
the AHP maps identified the suitable areas as scattered regions, while the Fuzzy model generated a map with clustered suitable areas.

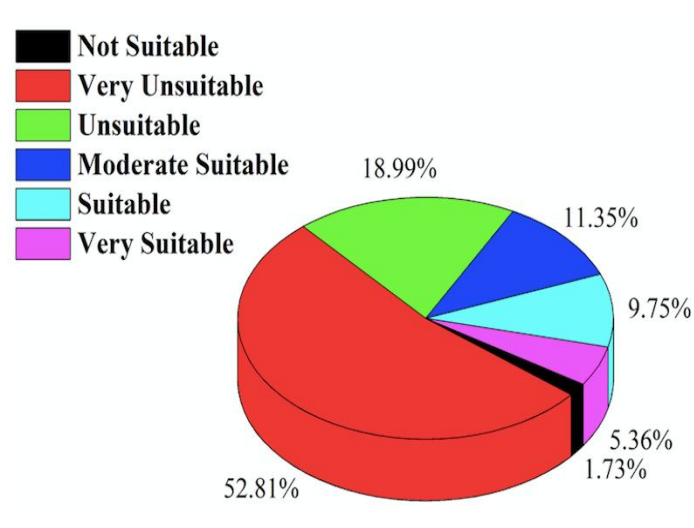

A

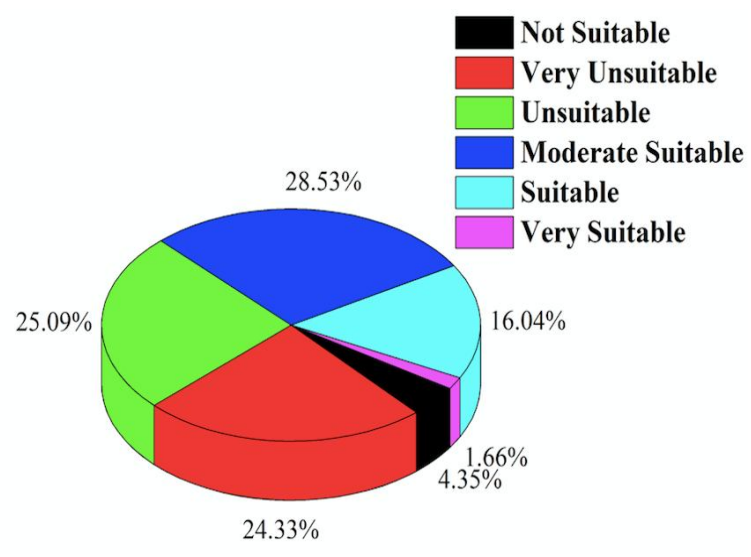

B

Figure 6. Percentage of landfill suitability A) fuzzy model and B) AHP model

Table 3. The results of AHP and fuzzy models

\begin{tabular}{c|c|c|c|c|c|c|c|c}
\hline \multirow{2}{*}{ Suitability class } & \multicolumn{2}{|c|}{ Cell count } & \multicolumn{2}{c|}{ Area $\left.\mathbf{( m}^{\mathbf{2}}\right)$} & \multicolumn{2}{c|}{ Area $\left.\mathbf{( k m}^{\mathbf{2}}\right)$} & \multicolumn{2}{c}{ Percentage (\%) } \\
\cline { 2 - 9 } & AHP & Fuzzy & AHP & Fuzzy & AHP & Fuzzy & AHP & Fuzzy \\
\hline Not suitable & 12036 & 4790 & 10832400 & 4311000 & 10.83 & 4.31 & 4.35 & 1.73 \\
Very unsuitable & 67332 & 146178 & 60598800 & 131560200 & 60.60 & 131.56 & 24.33 & 52.81 \\
Unsuitable & 69456 & 52570 & 62510400 & 47313000 & 62.51 & 47.31 & 25.09 & 18.99 \\
Moderate suitable & 78969 & 31411 & 71072100 & 28269900 & 71.07 & 28.27 & 28.53 & 11.35 \\
Suitable & 44389 & 26997 & 39950100 & 24297300 & 39.95 & 24.30 & 16.04 & 9.75 \\
Very suitable & 4600 & 14836 & 4140000 & 13352400 & 4.14 & 13.35 & 1.66 & 5.36 \\
Total area & $\mathbf{2 7 6 7 8 2}$ & $\mathbf{2 7 6 7 8 2}$ & $\mathbf{2 4 9 1 0 3 8 0 0}$ & $\mathbf{2 4 9 1 0 3 8 0 0}$ & $\mathbf{2 4 9 . 1 0}$ & $\mathbf{2 4 9 . 1 0}$ & $\mathbf{1 0 0}$ & $\mathbf{1 0 0}$ \\
\hline
\end{tabular}

However, a field visit is required to confirm the final location for the landfill site in order to take into account other factors that were excluded in the model, such as the population and other environmental changes. There may be some changes to the sites that may not be favorable for the intended purposes. Therefore, a field investigation was conducted to further assess the reliability of the proposed methodology. A handheld GPS device (GeoExplorer 6000) was used to determine the location of the sites. Figure 7 shows the location of the most suitable sites obtained during field investigation. The information acquired from field measurements allow for the assessment of the precision and reliability of the produced suitable areas for waste disposal landfill.

Several studies have been conducted for the site selection and disposal of the solid wastes by applying multi-criteria decision analysis (MCDA) using GIS as shown in Table 4. However, in this work shown Fuzzy logic was more accurate than AHP. The most significant physical parameters were derived and then ranked according to their contribution to landfill. This model is a first attempt in our study area. We optimized knowledge driven method by data driven approach in order to minimize the spatial errors. 

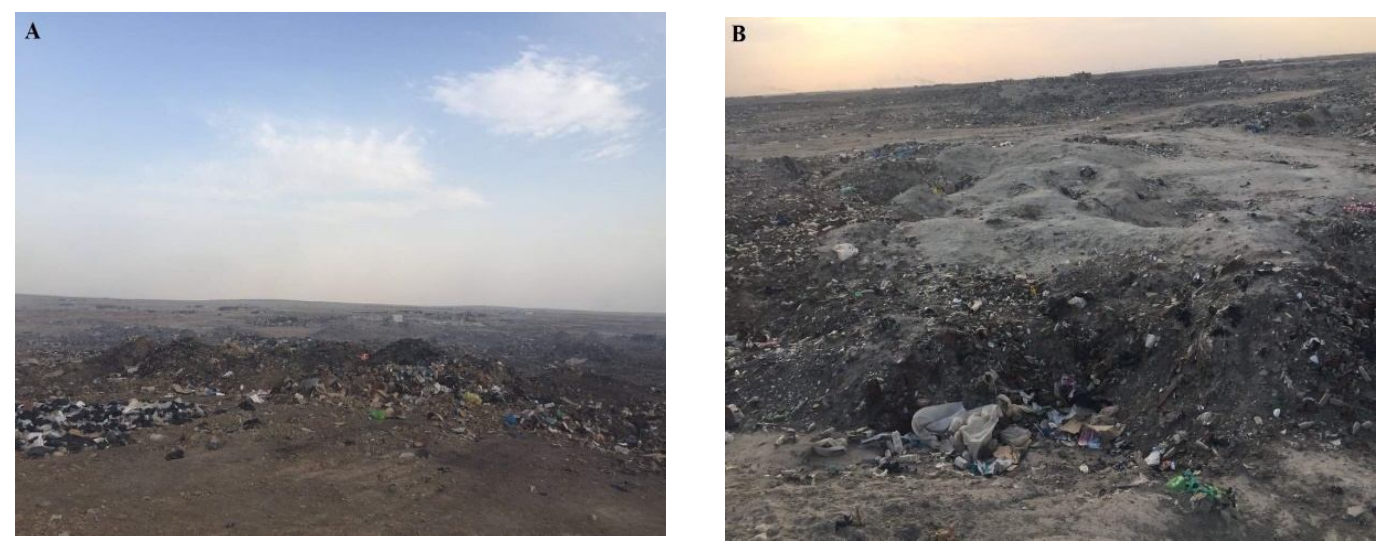

Figure 7. The most suitable sites identified during field investigation $\left(A: 31^{\circ} 3{ }^{\prime} 32.81^{\prime \prime} \mathrm{N}\right.$, $46^{\circ} 13^{\prime} 41.20^{\prime \prime} E$; $B$ : $\left.31^{\circ} 0^{\prime} 27.49^{\prime \prime} N, 46^{\circ} 11^{\prime} 5.09^{\prime \prime} E\right)$

Table 4. The comparison of technique of landfill site selection

\begin{tabular}{|c|c|c|c|}
\hline Study area & Technique & Criteria & References \\
\hline Mexico & MCDM and GIS & $\begin{array}{c}\text { Social, economic and } \\
\text { environmental criteria, } \\
\text { proximity cost consideration }\end{array}$ & Delgado et al. (2008) \\
\hline Northern Italy & $\begin{array}{l}\text { MCDM, simple } \\
\text { additive weighting }\end{array}$ & $\begin{array}{l}\text { Social, economic and } \\
\text { environmental criteria }\end{array}$ & Geneletti (2010) \\
\hline Karaj, Iran & $\begin{array}{c}\text { GIS, cluster analysis, } \\
\text { AHP }\end{array}$ & $\begin{array}{l}\text { Social, economic and } \\
\text { environmental criteria }\end{array}$ & Moeinaddini et al. (2010) \\
\hline Iran & $\begin{array}{l}\text { AHP for weights, } \\
\text { GIS, simple additive } \\
\text { weighting }\end{array}$ & $\begin{array}{l}\text { Social, economic and } \\
\text { environmental criteria }\end{array}$ & Eskandari et al. (2012) \\
\hline Macedonia & $\begin{array}{l}\text { MCDM: AHP and } \\
\text { ordered weighted } \\
\text { average }\end{array}$ & $\begin{array}{l}\text { Economic and environmental } \\
\text { criteria }\end{array}$ & Gorsevski et al. (2012) \\
\hline Turkey & AHP for weights & $\begin{array}{l}\text { Social, economic and } \\
\text { environmental criteria }\end{array}$ & Yildirim (2012) \\
\hline Iraq & MCDM and GIS & $\begin{array}{l}\text { Social, economic and } \\
\text { environmental criteria }\end{array}$ & $\begin{array}{c}\text { Mohammad Ali Al-Anbari } \\
\text { (2014) }\end{array}$ \\
\hline \multirow[t]{2}{*}{ Morocco } & \multirow{2}{*}{$\begin{array}{l}\text { MCDM, GIS and } \\
\text { remote sensing }\end{array}$} & \multirow{2}{*}{$\begin{array}{l}\text { Social, economic and } \\
\text { environmental criteria }\end{array}$} & $\begin{array}{l}\text { Abdelhakim El Maguiri } \\
\text { (2016) }\end{array}$ \\
\hline & & & Zeinhom El Alfy (2018) \\
\hline Mansoura city, Egypt & MCDM, GIS, AHP & $\begin{array}{l}\text { Social, economic and } \\
\text { environmental criteria }\end{array}$ & Zeinhom El Alfy (2018) \\
\hline Nasiriyah city, Iraq & $\begin{array}{l}\text { MCDM, GIS and } \\
\text { Fuzzy logic, AHP }\end{array}$ & $\begin{array}{l}\text { Social, economic and } \\
\text { environmental criteria }\end{array}$ & Present study \\
\hline
\end{tabular}

\section{Conclusion}

In this study, 12 criteria were used in an overlaying analysis of potential areas with GIS to identify a suitable landfill site in Nasiriyah, Iraq. A combination of GIS, AHP and Fuzzy logic models were used in this study; layers such as slope, distance from bodies of water, distance from roads, distance from railways, distance from open space, distance from agricultural lands, distance from health centers and hospitals, distance 
from residential areas, distance from commercial areas, distance from industrial areas, distance from facilities, and distance from educational areas were considered. The criteria weightings were derived from the AHP method by constructing a matrix of pairwise comparisons between criteria.

This study found the areas identified by both methods as most suitable, which were observed to be outside of the city boundary, mostly to the west and south of the study area and met the requirements of environmental, economic and residential factors. The common areas identified in both methods showed the most suitable lands for waste disposal landfill with an appropriate distance from residential areas and open space. Therefore, the result showed that a combination of GIS, AHP and Fuzzy models using multi-scientific and environmental criteria could be used to develop an effective and efficient methodology for selecting suitable landfill sites in Nasiriyah, Iraq. It can be concluded that the methodology applied in the present study is capable in locating the suitable landfill site in Nasiriyah city, thus future study should be carried out as well at other provinces in Iraq. It is recommended that future study should consider other important parameters such as soil type, soil layer stratification, levels and movements of the groundwater, etc. These parameters need to be studied in detail and field work analysis needs to be conducted for providing accurate and comprehensive study.

Acknowledgements. Marlia M. Hanafiah was supported by the Universiti Kebangsaan Malaysia (DIP2017-006) and the Ministry of Education Malaysia (FRGS/1/2018/WAB05/UKM/02/2).

\section{REFERENCES}

[1] Abdullahi, S., Mahmud, A. R. B., Pradhan, B. (2014): Spatial modelling of site suitability assessment for hospitals using geographical information system-based multicriteria approach at Qazvin city, Iran. - Geocarto International 29(2): 164-184.

[2] Al-Anbari, M. A., Al-Ansari, N., Jasim, H. K. (2014): GIS and multicriteria decision analysis for landfill site selection in AL-HashimyahQadaa. - Natural Science 6(5): 282304.

[3] Amato, F., Tonini, M., Murgante, B., Kanevski, M. (2018): Fuzzy definition of rural urban interface: an application based on land use change scenarios in Portugal. Environmental Modelling \& Software 104: 171-187.

[4] Ayalew, L., Yamagishi, H., Ugawa, N. (2004): Landslide susceptibility mapping using GIS-based weighted linear combination, the case in Tsugawa area of Agano River, Niigata Prefecture, Japan. - Landslides 1: 73-81.

[5] Beskese, A., Demir, H. H., Ozcan, H. K., Okten, H. E. (2015): Landfill site selection using Fuzzy AHP and Fuzzy TOPSIS: a case study for Istanbul. - Environmental Earth Sciences 73(7): 3513-3521.

[6] Chabuk, A., Al-Ansari, N., Hussain, H. M., Knutsson, S., Pusch, R., Laue, J. (2017): Combining GIS applications and method of multi-criteria decision-making (AHP) for landfill siting in Al-Hashimiyah Qadhaa, Babylon, Iraq. - Sustainability 9(11): 1932.

[7] Delgado, O. B., Mendoza, M., Granados, E. L., Geneletti, D. (2008): Analysis of land suitability for the siting of inter-municipal landfills in the Cuitzeo Lake Basin, Mexico. Waste Management 28(7): 1137-1146.

[8] Drobne, S., Lisec, A. (2009): Multi-attribute decision analysis in GIS: weighted linear combination and ordered weighted averaging. - Informatica 33: 459-474.

[9] Eastman, J. R. (2003): IDRISI Kilimanjaro: guide to GIS and image processing. - Idrisi Production, Clark University. 
[10] El Alfy, Z., Elhadary, R., Elashry, A. (2010): Integrating GIS and MCDM to deal with landfill site selection. - International Journal of Engineering \& Technology 10(6): 32-42.

[11] El Baba, M., Kayastha, P., De Smedt, F. (2015): Landfill site selection using multicriteria evaluation in the GIS interface: a case study from the Gaza Strip, Palestine. Arabian Journal of Geosciences 8(9): 7499-7513.

[12] El Maguiri, A., Kissi, B., Idrissi, L., Souabi, S. (2016): Landfill site selection using GIS, remote sensing and multicriteria decision analysis: case of the city of Mohammedia, Morocco. - Bulletin of Engineering Geology and the Environment 75(3): 1301-1309.

[13] Eskandari, M., Homaee, M., Mahmodi, S. (2012): An integrated multi criteria approach for landfill siting in a conflicting environmental, economical and socio-cultural area. Waste Management 32(8): 1528-1538.

[14] Foroughian, A., Eslami, H. (2015): Application of AHP and GIS for landfill site selection (A case study: city of Susa). - Journal of Scientific Research and Development 2(5): 129134.

[15] Gbanie, S. P., Tengbe, P. B., Momoh, J. S., Medo, J., Kabba, V. T. S. (2013): Modelling landfill location using geographic information systems (GIS) and multi-criteria decision analysis (MCDA): case study Bo, Southern Sierra Leone. - Applied Geography 36: 3-12.

[16] Geneletti, D. (2010): Combining stakeholder analysis and spatial multicriteria evaluation to select and rank inert landfill sites. - Waste Management 30(2): 328-337.

[17] Gorsevski, P. V., Jankowski, P., Gessler, P. E. (2006): An heuristic approach for mapping landslide hazard by integrating fuzzy logic with analytic hierarchy process. - Control and Cybernetics 35: 121-146.

[18] Gorsevski, P. V., Donevska, K. R., Mitrovski, C. D., Frizado, J. P. (2012): Integrating multi-criteria evaluation techniques with geographic information systems for landfill site selection: a case study using ordered weighted average. - Waste Management 32(2): 287296.

[19] Hanine, M., Boutkhoum, O., Tikniouine, A., Agouti, T. (2016): Comparison of fuzzy AHP and Fuzzy TODIM methods for landfill location selection. - SpringerPlus 5: 501.

[20] Jiang, H., Eastman, J. R. (2000): Application of fuzzy measures in multi-criteria evaluation in GIS. - International Journal of Geographical Information Science 14(2): 173-184.

[21] Khorram, A., Yousefi, M., Alavi, S. A., Farsi, J. (2015): Convenient landfill site selection by using fuzzy logic and geographic information systems: A case study in Bardaskan, East of Iran. - Health Scope 4(1): e19383.

[22] Kritikos, T. R., Davies, T. R. (2011): GIS-based multi-criteria decision analysis for landslide susceptibility mapping at northern Evia, Greece [GIS-basierte multikriterielle Entscheidungsanalysen zur Kartierung von Massenverlagerungspotenzialen im nördlichen Evia, Griechenland]. - Zeitschrift der Deutschen Gesellschaft für Geowissenschaften 162(4): 421-434.

[23] Liu, H. C., You, J. X., Fan, X. J., Chen, Y. Z. (2014): Site selection in waste management by the VIKOR method using linguistic assessment. - Applied Soft Computing 21: 453461.

[24] Sreedevi, R. P., Vimala, V., Rameswari, P., Sateesh, S. (2016): an application of fuzzy logic and DEA in agriculture sector. - International Journal of Engineering Science 6(5): 4876-4878.

[25] Moeinaddini, M., Khorasani, N., Danehkar, A., Darvishsefat, A. A. (2010): Siting MSW landfill using weighted linear combination and analytical hierarchy process (AHP) methodology in GIS environment (case study: Karaj). - Waste Management 30(5): 912920.

[26] Qiu, F., Chastain, B., Zhou, Y., Zhang, C., Sridharan, H. (2014): Modeling land suitability/capability using fuzzy evaluation. - GeoJournal 79(2): 167-182.

[27] Önüt, S., Soner, S. (2008): Transshipment site selection using the AHP and TOPSIS approaches under fuzzy environment. - Waste Management 28(9): 1552-1559. 
[28] Rathore, S., Ahmad, S. R., Shirazi, S. A. (2016): Use of the suitability model to identify landfill sites in Lahore-Pakistan. - Journal of Basic and Applied Sciences 12: 103-108.

[29] Saaty, T. L. (1977): A scaling method for priorities in hierarchical structures. - Journal of Mathematical Psychology 15(3): 234-281.

[30] Saaty, T. L. (1980): The Analytic Hierarchy Process: Planning, Priority Setting, Resources Allocation. - McGraw Hill, New York.

[31] Saaty, T. L. (2000): Fundamentals of Decision Making and Priority Theory. - McGraw Hill, New York.

[32] Şener, Ş., Şener, E., Nas, B., Karagüzel, R. (2010): Combining AHP with GIS for landfill site selection: a case study in the Lake Beyşehir catchment area (Konya, Turkey). Waste Management 30(11): 2037-2046.

[33] Srivastava, A. K. Nema, A. K. (2012): Fuzzy parametric programming model for multiobjective integrated solid waste management under uncertainty. - Expert Systems with Applications 39(5): 4657-4678.

[34] Tavares, G., Zsigraiová, Z., Semiao, V. (2011): Multi-criteria GIS-based siting of an incineration plant for municipal solid waste. - Waste Management 31(9-10): 1960-1972.

[35] Torabi-Kaveh, M., Babazadeh, R., Mohammadi, S. D., Zaresefat, M. (2016): Landfill site selection using combination of GIS and Fuzzy AHP, a case study: Iranshahr, Iran. Waste Management \& Research 34(5): 438-448.

[36] Uyan, M. (2014): MSW landfill site selection by combining AHP with GIS for Konya, Turkey. - Environmental Earth Sciences 71(4): 1629-1639.

[37] Vaidya, O. S., Kumar, S. (2006): Analytic hierarchy process: an overview of applications. - European Journal of Operational Research 169(1): 1-29.

[38] Vasiljević, T. Z., Srdjević, Z., Bajčetić, R., Miloradov, M. V. (2012): GIS and the analytic hierarchy process for regional landfill site selection in transitional countries: a case study from Serbia. - Environmental Management 49(2): 445-458.

[39] Yildirim, V. (2012): Application of raster-based GIS techniques in the siting of landfills in Trabzon Province, Turkey: a case study. - Waste Management \& Research 30(9): 949960.

\section{APPENDIX}

Table A1. Sub-criteria factors extracted from main criteria

\begin{tabular}{c|c}
\hline Main criteria & Sub-criteria \\
\hline G) Geomorphology parameter & G1) Slope \\
\hline H) Hydrology & H1) Distance from water bodies \\
\hline T) Transporting parameters & T1) Distance from railway \\
& T2) Distance from road \\
\hline & L1) Distance from educational areas \\
& L2) Distance from facilities and services \\
L) Land use parameters & L3) Distance from health centres and hospitals \\
& L4) Distance from commercial areas \\
& L5) Distance from agricultural areas \\
L6) Distance from industrial areas \\
L7) Distance from residential areas \\
L8) Distance from open space
\end{tabular}


Table A2. Fundamental scale of AHP multi criteria decision making

\begin{tabular}{c|c}
\hline \multicolumn{2}{c}{ Fundamental scale (row v column) } \\
\hline Extremely less important & $1 / 9$ \\
Very strongly less important & $1 / 8$ \\
Strongly less important & $1 / 7$ \\
& $1 / 6$ \\
Moderately less important & $1 / 5$ \\
& $1 / 4$ \\
Equal importance & $1 / 3$ \\
& $1 / 2$ \\
Moderately more important & 1 \\
Strongly more important & 2 \\
& 3 \\
Very strongly more important & 4 \\
Extremely more important & 5 \\
\hline
\end{tabular}

Table A3. Sub-classes and rank of slope, distance from river, distance from roads, distance from railways, distance from open space, distance from agricultural lands, distance from health centres and hospitals, distance from residential areas, distance from commercial areas, distance from industrial areas, distance from facilities areas and distance from education areas

\begin{tabular}{|c|c|c|c|}
\hline \multicolumn{4}{|c|}{ Slope } \\
\hline From (degree) & To (degree) & Average (degree) & Rank \\
\hline 0 & 0 & 0 & 6 \\
\hline 0 & 2 & 1 & 5 \\
\hline 2 & 5 & 3.5 & 4 \\
\hline 5 & 10 & 7.5 & 3 \\
\hline 10 & 20 & 15 & 2 \\
\hline 20 & 45 & 32.5 & 1 \\
\hline \multicolumn{4}{|c|}{ River (meter) } \\
\hline From (meter) & To (meter) & Average (meter) & Rank \\
\hline 0 & 183 & 91 & 1 \\
\hline 183 & 496 & 339 & 2 \\
\hline 496 & 836 & 666 & 3 \\
\hline 836 & 1175 & 871 & 4 \\
\hline 175 & 1567 & 1005 & 5 \\
\hline 1567 & 1985 & 1776 & 6 \\
\hline 1985 & 2533 & 2259 & 7 \\
\hline 2533 & 3238 & 2885 & 8 \\
\hline 3238 & 4204 & 3721 & 9 \\
\hline 4204 & 6659 & 5431 & 10 \\
\hline
\end{tabular}




\begin{tabular}{c|c|c|c}
\hline \multicolumn{4}{c}{ Distance from the road } \\
\hline From (meter) & To (meter) & Average (meter) & Rank \\
\hline 0 & 0 & 0 & 1 \\
0 & 64 & 32 & 2 \\
64 & 169 & 116 & 3 \\
169 & 318 & 243 & 4 \\
318 & 487 & 402 & 6 \\
487 & 699 & 593 & 7 \\
699 & 953 & 826 & 5 \\
953 & 1313 & 1133 & 2 \\
1313 & 1969 & 1641 & 1 \\
1969 & 5398 & 3684 & 7 \\
\hline
\end{tabular}

\begin{tabular}{c|c|c|c}
\hline \multicolumn{2}{c}{ Distance from the railway } \\
\hline From (meter) & To (meter) & Average (meter) & Rank \\
\hline 0 & 792 & 396 & 1 \\
792 & 1641 & 1217 & 2 \\
1641 & 2546 & 2094 & 4 \\
2546 & 3508 & 3027 & 5 \\
3508 & 4584 & 4046 & 6 \\
4584 & 5829 & 5206 & 7 \\
5829 & 7356 & 6592 & 8 \\
7356 & 8828 & 8092 & 9 \\
8828 & 10356 & 9592 & 10 \\
10356 & 14430 & 12393 & \\
\hline
\end{tabular}

\begin{tabular}{c|c|c|c}
\hline \multicolumn{4}{c}{ Distance from open space (bare land) } \\
\hline From (meter) & To (meter) & Average (meter) & Rank \\
\hline 0 & 367 & 184 & 10 \\
367 & 735 & 551 & 8 \\
735 & 1102 & 918 & 7 \\
1102 & 1469 & 1286 & 6 \\
1469 & 1837 & 1653 & 5 \\
1837 & 2204 & 2020 & 4 \\
2204 & 2571 & 2387 & 2 \\
2571 & 2938 & 2755 & 1 \\
2938 & 3306 & 3122 & \\
3306 & 3673 & 3489 & Rank \\
\hline From (meter) & Distance from health & 1 \\
0 & To (meter) & Average (meter) & 2 \\
540 & 540 & 270 & 3 \\
1152 & 1152 & 846 & 4 \\
2377 & 1764 & 1458 & 5 \\
3637 & 2377 & 2071 & 6 \\
\hline 429 & 2989 & 2683 & 3313 \\
\hline
\end{tabular}




\begin{tabular}{|c|c|c|c|}
\hline $\begin{array}{l}5257 \\
6194 \\
\end{array}$ & $\begin{array}{l}6194 \\
9182 \\
\end{array}$ & $\begin{array}{l}5725 \\
7688 \\
\end{array}$ & $\begin{array}{c}9 \\
10 \\
\end{array}$ \\
\hline \multicolumn{4}{|c|}{ Distance from commercial } \\
\hline From (meter) & To (meter) & Average (meter) & Rank \\
\hline 0 & 855 & 428 & 1 \\
\hline 855 & 1853 & 1354 & 2 \\
\hline 1853 & 2672 & 2263 & 3 \\
\hline 2672 & 3385 & 3029 & 4 \\
\hline 3385 & 4026 & 3706 & 5 \\
\hline 4026 & 4632 & 4329 & 6 \\
\hline 4632 & 5238 & 4935 & 7 \\
\hline 5238 & 5844 & 5541 & 8 \\
\hline 5844 & 6592 & 6218 & 9 \\
\hline 6592 & 9086 & 7839 & 10 \\
\hline
\end{tabular}

\begin{tabular}{c|c|c|c}
\hline \multicolumn{3}{c}{ Distance from agriculture } & \multicolumn{2}{c}{ Rank } \\
\hline From (meter) & To (meter) & Average (meter) & 1 \\
0 & 0 & 0 & 2 \\
0 & 147 & 74 & 3 \\
314 & 319 & 233 & 4 \\
515 & 515 & 417 & 5 \\
785 & 785 & 650 & 6 \\
1154 & 1154 & 969 & 7 \\
1620 & 1620 & 1387 & 8 \\
2233 & 2233 & 1927 & 9 \\
3068 & 3068 & 2651 & 10 \\
\hline
\end{tabular}

\begin{tabular}{c|c|c|c}
\hline \multicolumn{3}{c}{ Residential } & \\
\hline From (meter) & To (meter) & Average (meter) & 1 \\
0 & 0 & 0 & 2 \\
179 & 179 & 90 & 3 \\
436 & 436 & 308 & 4 \\
718 & 718 & 577 & 5 \\
1051 & 1051 & 884 & 7 \\
1410 & 1410 & 1230 & 8 \\
1820 & 1820 & 1615 & 9 \\
2332 & 2332 & 2076 & 10 \\
3127 & 3127 & 2730 & 6 \\
\hline
\end{tabular}

\begin{tabular}{c|c|c|c}
\hline \multicolumn{5}{c}{ Industrial } \\
\hline From (meter) & To (meter) & Average (meter) & Rank \\
\hline 0 & 403 & 201 & 1 \\
403 & 906 & 655 & 3 \\
906 & 1376 & 1141 & 4 \\
1376 & 1880 & 1628 & 9 \\
2451 & 2451 & 2165 & 10 \\
\end{tabular}




\begin{tabular}{|c|c|c|c|}
\hline $\begin{array}{l}3089 \\
3861 \\
4902 \\
6110\end{array}$ & $\begin{array}{l}3861 \\
4902 \\
6110 \\
8561\end{array}$ & $\begin{array}{l}3475 \\
4381 \\
5506 \\
7336\end{array}$ & $\begin{array}{l}8 \\
7 \\
6 \\
5\end{array}$ \\
\hline \multicolumn{4}{|c|}{ Facilities } \\
\hline From (meter) & To (meter) & Average (meter) & Rank \\
\hline 0 & 164 & 82 & 1 \\
\hline 164 & 691 & 428 & 2 \\
\hline 691 & 1250 & 970 & 3 \\
\hline 1250 & 1842 & 1546 & 4 \\
\hline 1842 & 2401 & 2122 & 5 \\
\hline 2401 & 2960 & 2681 & 6 \\
\hline 2960 & 3651 & 3306 & 7 \\
\hline 3651 & 4572 & 4112 & 8 \\
\hline 4572 & 5625 & 5099 & 9 \\
\hline 5625 & 8388 & 7007 & 10 \\
\hline \multicolumn{4}{|c|}{ Distance from educational } \\
\hline From (meter) & To (meter) & Average (meter) & Rank \\
\hline 0 & 212 & 106 & 1 \\
\hline 212 & 672 & 442 & 2 \\
\hline 672 & 1238 & 955 & 3 \\
\hline 1238 & 1839 & 1539 & 4 \\
\hline 1839 & 2441 & 2140 & 5 \\
\hline 2441 & 3006 & 2724 & 6 \\
\hline 3006 & 3679 & 3342 & 7 \\
\hline 3679 & 4492 & 4085 & 8 \\
\hline 4492 & 5412 & 4952 & 9 \\
\hline 5412 & 9019 & 7216 & 10 \\
\hline
\end{tabular}

